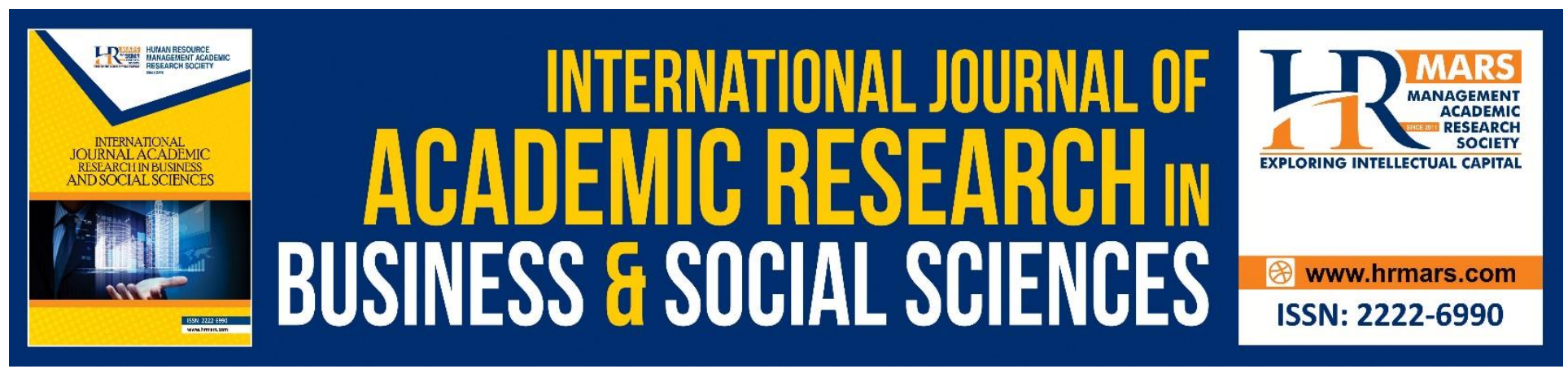

\title{
Environmental Accounting and Corporate Performance
}

\section{Fasua, Henry Kehinde and Osifo, Osagie Iguma Uwagboe}

To Link this Article: http://dx.doi.org/10.6007/IJARBSS/v10-i9/7711

DOI:10.6007/IJARBSS/v10-i9/7711

Received: 15 June 2020, Revised: 19 July 2020, Accepted: 23 August 2020

Published Online: 13 September 2020

In-Text Citation: (Fasua, and Osifo, 2020)

To Cite this Article: Fasua, H. K., and Osifo, O. I. U.(2020). Environmental Accounting and Corporate Performance. International Journal of Academic Research in Business and Social Sciences. 10(9), 142-154.

\section{Copyright: (C) 2020 The Author(s)}

Published by Human Resource Management Academic Research Society (www.hrmars.com)

This article is published under the Creative Commons Attribution (CC BY 4.0) license. Anyone may reproduce, distribute, translate and create derivative works of this article (for both commercial and non-commercial purposes), subject to full attribution to the original publication and authors. The full terms of this license may be seen

at: http://creativecommons.org/licences/by/4.0/legalcode

\section{Vol. 10, No. 9, 2020, Pg. 142 - 154}

Full Terms \& Conditions of access and use can be found at http://hrmars.com/index.php/pages/detail/publication-ethics 


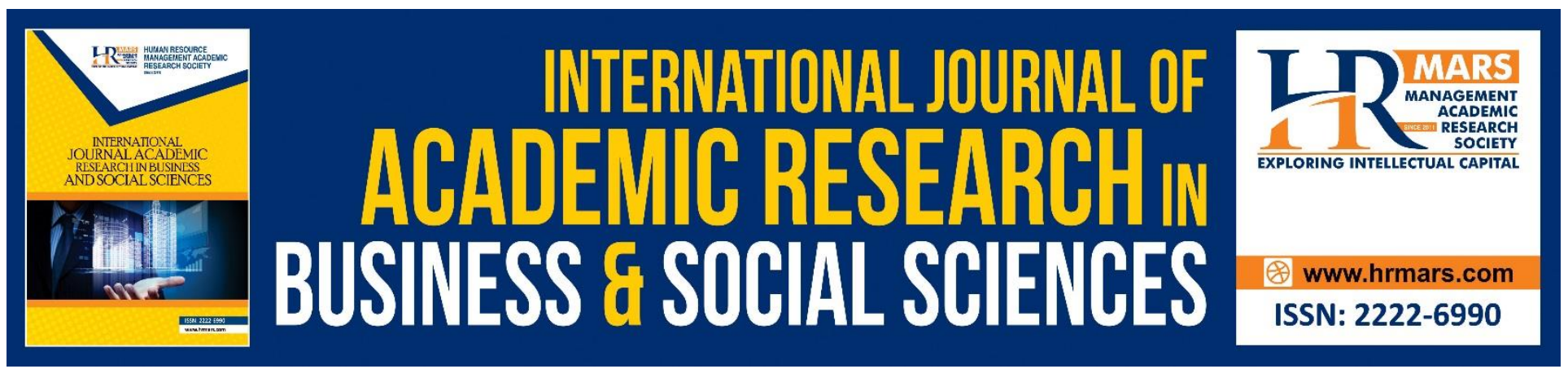

\title{
Environmental Accounting and Corporate Performance
}

\section{Fasua, Henry Kehinde (ACA) and Osifo, Osagie Iguma Uwagboe (FCA) \\ University of Benin, Edo State, Nigeria, Faculty of Management sciences, Accounting Department}

\begin{abstract}
Environmental accounting is one of current issues under Corporate Social Responsibility (CSR) in Nigeria that focuses on cost implications for management of emission, greenhouse gasses and pollution created in the cause of achieving organizational objectives. It is essential to consider cost and benefits analysis. The objective of this study is to establish effects of corporate performance on environmental accounting disclosure and examine kind of significant relationship that subsists between environmental accounting and corporate performance of firms in Nigeria.

The data for the study were collected from annual reports and accounts of 18 randomly selected quoted firms in the Nigerian stock exchange. The data were analyzed with the panel regression analysis method.

The key findings of the study show that there are statistically significant positive relationships between Environmental Accounting (EA) and Return on Asset (ROA); and Net profit Margin (NPM) as well as a statistically significant negative relationship between Environmental Accounting (EA) and Earnings per Share (EPS).

Based on this the study is recommended that government should give tax credit to organizations that comply with its environmental laws and that environmental reporting should be made compulsory in Nigeria in order for other stake-holders to be properly informed and have sense of being in the right place.
\end{abstract}

Keywords: Environmental Accounting, Return on Asset, Net profit Margin

\section{Introduction}

Many companies are created with only objective of maximization of owners' wealth without considering its economic footprints on the other stakeholders as well as the community at large. The activities of many companies such as oil and gas companies and manufacturing companies do generate negative impacts which are called social failure and threats. These include deforestation, elimination of marine fisheries, increased atmosphere carbon dioxide, increased climatic disruption, persistent deposit of toxic chemicals in human beings, constant melting of mountain, increased health hazard caused by the sound and smoke emission from generators and factory plants (Jepkogei, Chumba \& Bongoko, 2015; Eze, Nweze \& Enekwe, 2016; Amacha \& Dastane, 2017; Dembo, 2017). 
INTERNATIONAL JOURNAL OF ACADEMIC RESEARCH IN BUSINESS AND SOCIAL SCIENCES Vol. 10, No. 9, 2020, E-ISSN: 2222-6990 @ 2020 HRMARS

Although these have been identified by international communities and on this premise Global Reporting Initiative was established to promote the course of environmental reporting, yet continuous researches are essential to improve on its measure and to identify its impacts that affect other stakeholders; as well to find out how corporate performance affects environmental accounting disclosure. Most of ample empirical literature on environmental reporting disclosure and corporate performance show contradicting outcomes, as it will be disclosed in the empirical reviews of related literature later. These contradicting results and findings necessitate the need for more research works to be carried out on the association that exists between environmental reporting disclosure and firm performance in Nigeria. Besides, to the best researcher's knowledge there is dearth of research work on: effects of firm performance on environmental accounting disclosure. Most available studies focus on effects of environmental accounting on firm performance. Therefore, more research studies are needed to be carried out on effects of corporate performance on environmental reporting disclosure.

The focus of this study is to investigate the impacts of firm performance on environmental accounting disclosure. Besides, its specific aims are to evaluate Returns on Assets (ROA) on environmental accounting disclosure, Net Profit Margin (NPM) on environmental accounting disclosure and earnings per share on environmental accounting disclosure. In order to appeal to empirical evidence data were collected from the Nigerian Stock Market from 2014 to 2018. This study will benefit the potential stakeholders, shareholders, and Nigerian firms at large premised on the fact that it will serve as a stimulant call to different firms to value the need and the magnitude of engaging environmental reporting disclosure.

\section{Literature Review}

\section{Environmental Accounting}

According to Fasua (2019), environmental accounting is a process of providing data either monetary or nonmonetary on the effect of entities operations to management to enhance them in capital budgeting decision, pricing decisions and controlling overheads. This process is to ensure ecoefficiency. Eco-efficiency is the procedures of lowing cost per unit of goods by making efforts that resources, energy utilization as well as waste are lessen to the barest minimum. This can be estimated by factoring in environmental costs using acceptable methods such as: eco- accounting, full cost accounting or life cycle costing (Kalu, 2014).

\section{Stakeholder Theory}

This theory focuses on various stakeholders who have diverse powers and positions on the operations of a firm. It has an interest in the environmental performance of the firm (Roberts, 1992). In the content of this theory, stakeholders include: creditors, managers, suppliers, customers, employees, government, the local community and the public as a whole. This theory holds that a firm will react to the expectations of influential stakeholders via disclosures. This theory spells out undoubtedly the factors that motivate managements' attitude in relation to environmental reporting practices of firms. The going concern concept for a firm is only possible if the stakeholders support the operations of the firm. For this to materialize, corporate operations must be centered towards meeting their needs (Gray, Kouhy \& Lavers, 1995). Stakeholders are deemed vital to a firm since they have direct control over resources that are required for carrying out the business (ICAN, 2019). Environmental 
INTERNATIONAL JOURNAL OF ACADEMIC RESEARCH IN BUSINESS AND SOCIAL SCIENCES Vol. 10, No. 9, 2020, E-ISSN: 2222-6990 @ 2020 HRMARS

reporting is thus one medium of encouraging stakeholders so that they discharge their duty towards the firm.

\section{Legitimacy Theory}

This theory of environmental accounting holds that the degree of environmental reporting determines by the environmental pressure that the firm encounters with regard to its environmental performance (Cho \& Patten, 2007). Company reacts to the pressure emanating from the community by disclosing environmental reports. Entity strives to strike balance between societal and their own values. The operation results to a social agreement between the entity and the community. Entities are considered to exist to the degree that the community deems them legitimate. Entities can employ disclosures to influence the community's perception about their entities. When communities discover that the entities' values are not matching the society's environmental values, it is deemed infringe of societal contract due to this the entity's going concern will be threatened (Milne \& Pattern, 2002). Entities that contravene societal contract attempt to restore it by disclosing positive environmental reports. Entities that are not in breaking of societal bond are required to disclose their environmental practice on a constant basis to guarantee good legitimacy. The more lucrative entities are expected to be more environmentally responsive. This theory is consistent with the assertion that entities that are lucrative are in a place to provide for environmental disclosure costs.

\section{Environmental Accounting and Corporate Performance}

Magara, Aming and Momanyi (2015) write a paper on the effect of environmental accounting on company financial performance in Kisii country and adopt a stratified sampling design using questionnaire and secondary data and discover that environmental accounting is significantly positively associated with corporate performance. Rahman and Muttakin (2005) specify that environmental accounting is an inclusive field of accounting. It provides reports for both internal uses, generating environmental information to help in making management decisions on pricing, controlling overhead and capital budgeting, and external use, disclosing environmental information of interest to the public and to the financial community.

Ramamurti (2004) states that environmental accounting enables organizations to track their environmental data and other greenhouse gas (GHG) emissions against reduction targets, and facilitates environmental reporting to provide sustainability related data that is comprehensive, auditable, and timely to advance and strengthen the interdependent and mutually reinforcing pillars of sustainable development - economic development, social development and environmental protection in Nigeria. Brown, Kercher, Nguyen, Nagle and Ball (2006) observe that consumers and investors are demonstrating increased interest in supporting responsible business practices and are demanding more information as to how companies address risks and opportunities relating to environmental issues.

\section{Return on Assets and Environmental Accounting}

Kihamba (2017) does a study on the relationship between environmental accounting and reporting practices and profitability of manufacturing firms listed in the Nairobi security exchange. The author uses descriptive research design and period of study was for 2014 to 2016 . Regression is employed to determine the association between environmental accounting and profitability. The study discovers that Environmental accounting has a positive relationship with return on assets. 
INTERNATIONAL JOURNAL OF ACADEMIC RESEARCH IN BUSINESS AND SOCIAL SCIENCES Vol. 10, No. 9, 2020, E-ISSN: 2222-6990 @ 2020 HRMARS

Ezeagba, John -Akamelu \& Umeoduagu (2017) research on environmental accounting disclosure and return on assets and discover that there is a significant positive relationship between environmental accounting and return on asset of selected companies.

Belkaoui and Kirkpik (1989) write on determinants of the corporate decision to disclose social information and their findings show a significantly pair-wise correlation, yet an insignificant negative regression co-efficient for return on assets and environmental disclosure. Mogaka and Janongo (2013) do a study on a relationship that subsists between environmental accounting and profitability of firms listed in Indian. Data were collected from annual reports and accounts of 14 companies quoted in Bombay stock exchange. The 14 companies were randomly selected multiple regression model was used to analyze data and the key findings revel a significant positive relationship between environmental accounting and return on assets.

Rakiv, Fakhrul and Raham (2016) do a study to find out the relationship between environmental accounting reporting disclosure and company's profitability, a case study on the listed manufacturing firms of Bangledsh. This study was an exemplary research that utilized secondary data sources obtained from annual reports. A disclosure index was developed using 21 major environmental disclosures, content analysis was used to obtain the disclosure index while statistical techniques like mean, frequency, standard deviations, ANNOVA and Bi variate regression model analysis was used to analyse the data. The findings revel there is a significant positive relationship between environmental accounting and return on asset.

\section{Net Profit margin (Profitability) and Environmental Accounting}

Mogaka and Janongo (2013) examine a relationship that exists between environmental accounting and profitability of firms listed in Indian. Secondary data were used from 14 companies were randomly selected multiple regression model was used to analyse data and their findings show a significant positive relationship between environmental accounting and profitability. Rakiv et al (2006) do a study to find out the relationship between environmental accounting reporting disclosure and company's profitability, a case study on the listed manufacturing firms of Bangledsh. The findings revel that a significant positive relationship exists between environmental accounting and profitability

Waddock and Gravess (1997) carry out research on the corporate social performance financial performance and find a positive association between profitability and environmental accounting. There are some researchers who used log of profits and among these researchers, is Roberts (1991) who found a positive relationship between profitability level of a company and corporate social and environmental disclosure. However, Patten (1991) discovered negative relationship between profitability and corporate social and environmental disclosure.

Ezeagba et al (2017) examine environmental accounting disclosures correlation with financial performance (ROE, ROCE, NPM) of food and beverage companies in Nigeria. Data were gathered via secondary sources and analyzed using Pearsons correlation technique and multiple regression, with the aid of SPSS version 20.00. The outcome revealed that there is a significant correlation among environmental accounting disclosures and return on equity of selected companies. It also revealed a negative correlation among environmental accounting disclosures and the net profit margin of selected companies.

Arong, Ezugwu, and Egbere, (2014) ascertain the effects of environmental cost management on the profitability of the oil sector in Nigeria from 2004 to 2013. Data were gathered via Statistical 
INTERNATIONAL JOURNAL OF ACADEMIC RESEARCH IN BUSINESS AND SOCIAL SCIENCES Vol. 10, No. 9, 2020, E-ISSN: 2222-6990 @ 2020 HRMARS

Bulletin. The data obtained were analysed with multiple regression technique. The outcomes reveal that there is a significant association among environmental cost management and profitability of the Oil Sector in Nigeria. It was also discovered that there are established standards in Nigeria guiding environmental cost management in the Oil \& Gas Sector in Nigeria.

Rakiv et al (2016) also assess the relationship of company profitability and extent of environmental accounting reporting disclosures in the annual reports in quoted manufacturing companies in DSE. For this research, an Environmental Accounting Reporting Disclosure Index (EARDI) is developed consisting of 21 major environmental accounting disclosures. Return on Asset (ROA) is used as the proxy variable for company profitability. To obtain the EARDI score, content analysis is being used and statistical techniques such as frequency, mean, standard deviation, ANNOVA, Bivariate regression model analysis was conducted to acquire research outcome. The research paper discloses that only 41 of 166 companies are providing some sort of environmental disclosures in their annual reports and there is a significant positive relation between company profitability and EARDI. Drawing a conclusion from only 41 companies out of 166 companies may not yield a better conclusion because 41 companies are too small.

\section{Earnings per Share and Environmental Accounting}

Mogaka and Janongo (2013) carry out a research work on a relationship that subsists between environmental accounting and profitability of firms listed in Indian. The researchers used secondary data from 14 companies were randomly selected multiple regression model was used to analyse data and the key findings revel a significant negative relationship between environmental accounting and earnings per share

\section{Methodology}

The population of this study is made up of all manufacturing companies listed at the floor of the Nigerian Stock Exchange (NSE) as at December, 2018. The study did select a sample from the population. On this ground, 18 manufacturing companies on the Nigerian Stock Exchange were accessible and used out of the entire listed manufacturing companies in the floor of the Nigerian Stock Exchange for this study based on filtering technique.

\section{Model Specification}

The study employed the panel data econometric model adapted in order to establish the relationship between the independent variable firm performance (proxies: Return on Assets (ROA), Net Profit Margin (NPM), Earnings per Share (EPS)) and the Dependent variable (EAD disclosure index). It adapted a model employed by Fasua (2019) with modification. The model for this study can be expressed as:

$\mathrm{EAD}=f(\mathrm{ROA}, \mathrm{NPM}$ and EPS)

The econometric form of the model is expressed as:

$Y=\beta_{0}+\beta_{1} x_{1}+\beta_{2} x_{2}+\beta_{3} x_{3}+\mu$------ (1)

That is,

$\mathrm{EAD}_{\mathrm{It}}=\beta_{0}+\beta_{1} \mathrm{ROA}_{\mathrm{it}}+\beta_{2} \mathrm{NPM}_{\mathrm{it}}+\beta_{3} \mathrm{EPS}_{\mathrm{it}}+\mu_{\mathrm{it}}$ 
INTERNATIONAL JOURNAL OF ACADEMIC RESEARCH IN BUSINESS AND SOCIAL SCIENCES Vol. 10, No. 9, 2020, E-ISSN: 2222-6990 @ 2020 HRMARS

\section{Data Presentation and Analysis}

\section{Operationalization of variables}

Table 4: Summary of Variables and their measurements

\begin{tabular}{|c|c|c|c|c|c|c|}
\hline$S / N$ & Variable (s) & Symbol & Operationalisation & Sources & & Apriori \\
\hline & $\begin{array}{l}\text { Dependent } \\
\text { Variable }\end{array}$ & & & & & \\
\hline \multirow[t]{2}{*}{1} & $\begin{array}{l}\text { Environmental } \\
\text { Accounting } \\
\text { Disclosure }\end{array}$ & EAD & Disclosure Index & NA & & \\
\hline & $\begin{array}{l}\text { Independent } \\
\text { Variables }\end{array}$ & & & & & \\
\hline 2 & Return on Assets & ROA & $\begin{array}{l}\text { Ratio of Profit After } \\
\text { Tax divided by Total } \\
\text { Assets. }\end{array}$ & $\begin{array}{l}\text { Ching, } \\
\text { and } \\
\text { (2017); } \\
\text { (2019) }\end{array}$ & $\begin{array}{l}\text { Gerab } \\
\text { Toste } \\
\text { Fasua }\end{array}$ & + \\
\hline 3 & Net Profit Margin & NPM & $\begin{array}{l}\text { Percentage of Profit } \\
\text { After Total and } \\
\text { Turnover }\end{array}$ & $\begin{array}{l}\text { Ching, } \\
\text { and } \\
(2017) ; \\
(2019)\end{array}$ & $\begin{array}{l}\text { Gerab } \\
\text { Toste } \\
\text { Fasua }\end{array}$ & + \\
\hline 4 & $\begin{array}{l}\text { Earnings Per } \\
\text { Share }\end{array}$ & EPS & $\begin{array}{l}\text { PAT/Number of } \\
\text { ordinary } \\
\text { shareholders }\end{array}$ & $\begin{array}{l}\text { Ching, } \\
\text { and } \\
(2017) ; \\
\text { (2019) }\end{array}$ & $\begin{array}{l}\text { Gerab } \\
\text { Toste } \\
\text { Fasua }\end{array}$ & - \\
\hline
\end{tabular}

\section{Sources: Authors Compilation based on Literature 2020}

\section{Data presentation analysis}

Table 4.2.1

Descriptive Statistics

$\begin{array}{lllll} & \text { EAD } & \text { ROA } & \text { NPM } & \text { EPS } \\ \text { Mean } & 0.891386 & 0.078835 & 0.031638 & 138.4081 \\ \text { Median } & 1.000000 & 0.060073 & 0.071855 & 23.45000 \\ \text { Maximum } & 1.000000 & 0.574184 & 5.297219 & 1316.600 \\ \text { Minimum } & 0.000000 & -0.162648 & -7.202432 & -294.0000 \\ \text { Std. Dev. } & 0.308856 & 0.122094 & 1.739271 & 292.2266 \\ \text { Skewness } & -0.400678 & 0.423041 & -0.055860 & 0.350592 \\ \text { Kurtosis } & 3.312747 & 3.321296 & 3.12214 & 2.526178 \\ & & & & \\ \text { Jarque-Bera } & 161.7329 & 159.8608 & 349.2541 & 195.2058 \\ \text { Probability } & 0.000000 & 0.000000 & 0.000000 & 0.000000 \\ & & & & \\ \text { Sum } & 79.33333 & 7.016339 & 2.815750 & 12318.32 \\ \text { Sum Sq. Dev. } & 8.394507 & 1.311811 & 266.2056 & 7514884 . \\ \text { Observations } & 89 & 89 & 89 & 89\end{array}$


INTERNATIONAL JOURNAL OF ACADEMIC RESEARCH IN BUSINESS AND SOCIAL SCIENCES Vol. 10, No. 9, 2020, E-ISSN: 2222-6990 @ 2020 HRMARS

\section{Author's Computation, 2020}

From the table 4.2 above shows the descriptive statistics for sample companies. An examination of the result reveals that EAD showed a mean value of 0.891 therefore indicating that on the average only $89 \%$ of sample manufacturing companies disclosed their level of engagement in environmental accounting activities. This table further shows 1.0000 and 0.0000 , explained in the maximum and minimum values respectively.

The standard deviation measuring the spread of the distribution stood at a value of 0.308 . The Jarque Bera statistics stood at a value of 161.73 with an associate probability of 0.00 thus, indicates that the variables are normally distributed when measure at critical level. This implies that the possibility of outlier does not exist in the distribution. An additional investigation tested at 5\% critical level. The mean values of the explanatory variables are positive. The skewness and kurtosis statistics of the variables were normally distributed as they are close to zero skewness and kurtosis of \pm 3 respectively. Thus, the variables exhibited normality.

Table 4.2.2: Correlation Analysis

$\begin{array}{lllll} & \text { EAD } & \text { ROA } & \text { NPM } & \text { EPS } \\ \text { EAD } & 1.000000 & & & \\ \text { ROA } & 0.128657 & 1.000000 & & \\ \text { NPM. } & 0.008333 & 0.181499 & 1.000000 & \\ \text { EPS } & -0.119628 & 0.127918 & 0.034220 & 1.000000\end{array}$

Table 4.2.2 shows Pearson correlation matrix for the variables as contained in the analysis. The correlation coefficients showed a relationship between the environmental accounting disclosures and corporate performance of manufacturing companies in Nigeria as contained in the analysis. The significant relationship is at $95 \%$ confidence level. Results demonstrated a significant relationship between environmental accounting disclosures and corporate performance. The correlation coefficients also showed a positive relationship between environmental accounting disclosures and return on assets, net profit margin except for earnings per share. Hence, most of these results are in conformity with the hypotheses with regard to the relationship between environmental accounting disclosures and return on assets, net profit margin and earnings per share. Hence, there is no problem about correlation as the correlation coefficients were less than 0.8 (Gujarati, 2004).

\section{Test of Hypotheses}

Analysis of Inflation of variance, Heteroskedasticity Test and Panel least square regression method were utilized to test the research hypotheses one to three. The regression analysis was engaged to examine the relationship between environmental accounting disclosure and corporate performance. In addition, the panel data regression method uses ordinary least square method with more statistically significant parameters. Table 4.3.3 presents the results of the panel least square regression method in order to analyze the relationship between and among the variables. 
INTERNATIONAL JOURNAL OF ACADEMIC RESEARCH IN BUSINESS AND SOCIAL SCIENCES Vol. 10, No. 9, 2020, E-ISSN: 2222-6990 @ 2020 HRMARS

Table 4.3.1

Variance Inflation Factor

\begin{tabular}{|c|c|c|c|}
\hline & Coefficient & Centered & Tolerance \\
\hline Variable & Variance & VIF & 1/VIF \\
\hline & & & \\
\hline C & 0.001714 & NA & \\
\hline ROA & 0.076809 & 1.050168 & 0.95222 \\
\hline NPM & 0.000373 & 1.034196 & 0.9669 \\
\hline EPS & $1.30 \mathrm{E}-08$ & 1.016765 & 0.9835 \\
\hline
\end{tabular}

Researcher's computation, 2020.

The variable inflation factor was utilized to check for multi-collinearlity. The rule of thumb indicates that they must be below the benchmark of 10. Therefore all the centered VIFs are below 10. The researcher now concludes that there is never an issue of multicollinerity in the model.

Table 4.3.3: Estimation of Panel Least Square Results

Dependent Variable: EAD

Method: Panel Least Squares

Date: 12/06/20 Time: 03:07

Sample: 20142018

Periods included: 5

Cross-sections included: 18

Total panel (unbalanced) observations: 89

\begin{tabular}{crrrr}
\hline \hline \multicolumn{1}{c}{ Variable } & Coefficient & Std. Error & t-Statistic & Prob. \\
\hline \hline ROA & 0.306989 & 0.277144 & 1.107686 & 0.0011 \\
NPM & 0.006031 & 0.019307 & 0.312370 & 0.0255 \\
EPS & -0.000111 & 0.000114 & -0.976482 & 0.0316 \\
C & 0.851976 & 0.041402 & 20.57806 & 0.0000 \\
\hline \hline R-squared & 0.628489 & Mean dependent var & 0.891386 \\
Adjusted R-squared & 0.605800 & S.D. dependent var & 0.308856 \\
S.E. of regression & 0.309750 & Akaike info criterion & 0.537803 \\
Sum squared resid & 8.155356 & Schwarz criterion & 0.649652 \\
Log likelihood & -19.93224 & Hannan-Quinn criter. & 0.582886 \\
F-statistic & 0.830859 & Durbin-Watson stat & 2.033282 \\
Prob(F-statistic) & 0.000541 & & & \\
\hline \hline
\end{tabular}

The results in table 4.3.3 shows that the Durbin Watson statistics of 2.033 shows the absence of autocorrelation or serial correlation between the variables as the coefficient is appropriately equal to 2 . The $\mathrm{R}^{2}$ value of 0.628489 connotes $62 \%$ of the degree of variation in the environmental accounting disclosure is explained by the model while the remaining $38 \%$ is captured by the stochastic 
INTERNATIONAL JOURNAL OF ACADEMIC RESEARCH IN BUSINESS AND SOCIAL SCIENCES Vol. 10, No. 9, 2020, E-ISSN: 2222-6990 @ 2020 HRMARS

error term. The estimated model is statistically significant in its overall evaluation considering the significance of the Prob. (F-statistic) value (0.000).

The various hypotheses formulated in chapter one is, therefore, tested in this section. The decision rule is that if the calculated P-value is lower than 5\% significant level, the alternate hypothesis is accepted and the null hypothesis is rejected. The restatement of the hypotheses and their results are as follows:

$\mathbf{H}_{01}$ : There is no significant relationship between environmental accounting disclosure and return on assets of manufacturing companies. Return on assets (ROA) has a significant positive relationship with environmental accounting (EA) disclosures at the probability level ( $p$-value) of 0.0011 and t-statistic of 1.108 at $5 \%$ significant level. This implies that the null hypothesis should be rejected while the alternate hypothesis accepted.

$\mathbf{H}_{02}$ : There is no significant relationship between net profit margin and environmental accounting in manufacturing companies. Net profit margin (NPM) has a significant positive relationship with environmental accounting (EA) disclosures at the probability level ( $p$-value) of 0.0255 and $t$ statistic of 0.31237 at $5 \%$ significant level. This indicates that null hypothesis should be rejected while the alternate hypothesis accepted.

$\mathbf{H}_{03}$ : There is no significant association between earnings per share and environmental accounting in manufacturing companies. Earnings per share (EPS) have a significant negative relationship with environmental accounting (EA) disclosures at the probability level ( $p$-value) of 0.0316 and t-statistic of -0.976482 at $5 \%$ significant level. This indicates that null hypothesis should be rejected while the alternate hypothesis accepted.

\section{Discussion of Findings}

The finding in respect of hypothesis one is in agreement with expectation, as environmental accounting disclosure exhibited a significant positive relationship with return on assets. The result showed that the P-values (0.0011) with T-statistic (1.108) were lower than the $5 \%$ significant level. Hence, the result supported the rejection of the null hypothesis as against the alternate hypothesis. The implication is that an increase in return on assets will result to an increase in the environmental accounting disclosure. The result is in conformity with the studies conducted by Kihamba (2017); Ezeagba et al (2017); Mogaka and Janongo (2013); and Rakiv et al (2006) where there is a significant positive relationship between return on assets and environmental accounting disclosures.

The findings from hypothesis two showed a significant positive relationship between net profit margin and environmental accounting disclosure in Nigerian manufacturing listed companies. The result showed that the P-values $(0.026)$ with T-statistic $(0.3124)$ were less than the $5 \%$ significant level. Thus, the result supported the acceptance of the alternate hypothesis as against the null hypothesis. This indicates that the higher net profit margin the higher environmental accounting disclosure. The result is in agreement with the work of Mogaka and Janongo (2013); Rakiv et al (2006); Waddock and Gravess (1997); Roberts (1991); Patten (1991); and Ezeagba et al (2017)

Hypothesis three, the findings showed a significant negative relationship between earnings per share and environmental accounting disclosure of listed manufacturing firms in Nigeria. The result revealed that the P-values $(0.0316)$ with T-statistic $(-0.976)$ were lower than the $5 \%$ significant level. Thus, the result supported the acceptance of the alternate hypothesis as against the null hypothesis. This indicates that a reduction in earnings per share leads to an increase disclosure of 
INTERNATIONAL JOURNAL OF ACADEMIC RESEARCH IN BUSINESS AND SOCIAL SCIENCES Vol. 10, No. 9, 2020, E-ISSN: 2222-6990 @ 2020 HRMARS

environmental accounting of the listed manufacturing companies in Nigeria. The result is consistent with the work of Mogaka and Janongo (2013).

\section{Summary of Findings, Conclusion and Recommendations Summary of Findings}

This study examined environmental accounting disclosure and performance of manufacturing companies and corporate performance. Hypotheses are developed based on the premise that manufacturing companies engage in environmental activities and incur environmental cost in order to reduce wastes and involve in environmental control. In addition, these companies are established to maximize shareholders' wealth and satisfy other stakeholders. The study finds that the engagement in environmental activities and accounting is associated with strong corporate performance.

Descriptive research design employed in this study allowed for quantitative data to be collected. The data were analysed through correlation and regression analysis to find out the nature and extent of relationship. Majority of the manufacturing firms listed on the NSE disclosed environmental activities of their firms. This is because the mean disclosure index was at $89 \%$. The practice of environmental accounting is positively correlated with corporate performance. Firms that this aspect of accounting disclosure expect more corporate performance levels. The other independent variables; return on assets and net profit margin have a significant positive relationship with environmental accounting disclosure while earnings per share have a significant negative relationship with environmental accounting disclosure.

\section{Conclusion}

This study has revealed that Environmental Accounting disclosure has a positive relationship with corporate performance of manufacturing firms listed on NSE. Manufacturing firms listed on the NSE should manage their impact on the environment and engage in public of their impacts and activities on the environment. The variables considered only contribute $62 \%$ of the overall corporate performance of manufacturing firms. The firms should therefore use environmental accounting practices as part of their strategy for corporate performance.

\section{Recommendations}

Based on the findings of this study the following recommendations are made:

1. Government should make Environmental Accounting in annual reports compulsory since most organizations hardly report their environmental activities in their report

2. Government agencies should give tax credit to firms that comply with its environmental laws of the land which will encourage environmental reporting.

3. Organisations on their part should ensure that they comply with the environmental laws of the nations as it will go a long way in enhancing their performance.

\section{Suggestions for Further Study}

This study only considered manufacturing firms listed on the NSE. Further research can be done factoring all the categories of firms listed on the NSE. Studies can also be carried out that will incorporate manufacturing firms not listed on the NSE. 
INTERNATIONAL JOURNAL OF ACADEMIC RESEARCH IN BUSINESS AND SOCIAL SCIENCES Vol. 10, No. 9, 2020, E-ISSN: 2222-6990 @ 2020 HRMARS

\section{Contribution to Knowledge}

Stakeholders are specifically interested in recognizing how their resources and environments are being managed. To the immediate communities and future generations is the vital indicator of the corporate performance when a firm is able to engage in corporate social responsibility and disclose them on the face of financial reports. The relationship between operations within the company's environment as well as environmental policies and returns of stakeholders eventually derive from return on their resources is a topical matter that attracts much attention of researchers and stakeholders. Empirical studies on the relationship between environmental accounting and corporate performance have built on the mixed findings obtained and the generalization of discoveries. In order to confirm the inconsistencies in literature, this paper contributes particularly to the body of knowledge by investing the effects of corporate performance on environmental accounting disclosure and kind of significant relationship that subsists between environmental accounting and corporate performance of firms in Nigeria. This study discovers that there are statistically significant positive relationships between Environmental Accounting (EA) and Return on Asset (ROA); and Net profit Margin (NPM) as well as a statistically significant negative relationship between Environmental Accounting (EA) and Earnings per Share (EPS).

\section{References}

Amacha, E. B., \& Dastane, O. (2017). Sustainability practices as determinants of financial performance: A Case of Malaysian Corporations. Journal of Asian Finance, Economics and Business, 4 (2), 55-68.

Arong, F. E., Ezugwu, C. I., \& Egbere, M. I. (2014). Environmental cost management and profitability of oil sector in Nigeria (2004-2013). Journal of Good Governance and Sustainable Development in Africa (JGGSDA), 2(2): 181-192.

Belkaoui, A., \& Karpik, P. G. (1989). Determinants of the corporate decision to disclose social information. Accounting, Auditing and Accountability Journal, 2(1): 36-51.

Brown, R. A., Kercher, A. K., Nguyen, T. H., Nagle, D. C., \& Ball, W. P. (2006). Production and characterization of synthetic wood chars for use as surrogates for natural sorbents. Organic Geochemistry, 37(3): 321-33.

Ching, H. Y., Gerab, F., \& Toste, T. H. (2017). The quality of sustainability reports and corporate financial performance: Evidence from Brazilian listed companies. SAGE Open, 7(2).

Cho, C. H., \& Patten, D. M. (2007). The role of environmental disclosures as tools of legitimacy: A research note. Accounting, Organizations and Society, 32(7/8): 639-647.

Dembo, A. M. (2017) The Impact of sustainability practices on the financial performance:

Evidence from listed oil and gas companies in Nigeria. Sustainability, Ethics \& $G$

Eze, J. C., Nweze, A. U., \& Enekwe, C. I. (2016). The effects of environmental accounting on a developing nation: Nigerian experience. European Centre for Research Training and development UK, 4(1): 17- 27.

Ezeagba, C. E., John - Akamelu, C. R., \& Umeoduagu, C. (2017). Environmental accounting disclosure and financial performance: A study of selected food and beverage companies in Nigeria. International Journal of Academic Research in Business and Social Sciences,7(9): 162- 174.

Fasua, H. K. (2019). The environmental activities and social effects on eternal stakeholders. Unpublished. 
INTERNATIONAL JOURNAL OF ACADEMIC RESEARCH IN BUSINESS AND SOCIAL SCIENCES

Vol. 10, No. 9, 2020, E-ISSN: 2222-6990 @ 2020 HRMARS

Gray, R., Kouhy, R., \& Lavers, S. (1995). Corporate social and environmental reporting; Areview of the literature and a longitudinal study of UK. disclosure. Accounting Auditing and Accountability Journal, 8 (2): $47-77$.

Gujarati, D. N. (2004). Basic econometric (4th ed). The McGrarv- Hill Companies.

I C AN. (2019). Study text: Management, government and ethics. United Kingom: Emile Woolf International Bracknell Ennterprise \& Innovation Hub.

Jepkogei, P., Chumba. S., \& Bongoko, J. (2015). Environmental accounting practices in business: A case of large petrol filling stations in Eldoret municipality. International Journal of Current Research, 7(4): 14748-14756

Kalu, U. (2014). Advanced financial reporting and ethics. Lagos

Kihamba, R. I. (2017). The relationship between environmental accounting and reporting practices and profitability in manufacturing firms on the Nairobi securities exchange. A research project submitted in partial fulfilment of the requirements of master of business administration, school of business, University of Nairobi.

Magara, R., Aming, A., \& Momanyi, E. (2015). Effect of environmental accounting on company financial performance in Kisii country. British Journal of Economics, Management and Trade, 10(1): 1-11

Milne, M. J., and Patten, D. M. (2002). Securing organizational legitimacy: An experimental decision case examining the impact of environmental disclosures.Accounting,Auditing \& Accountability Journal, 15(3): 372-405.

Mogaka, D. M., \& Jagongo, A. (2013) Environmental accounting and firm profitability: An empirical analysis of selected firms listed in Bombay Stock Exchange, India. International Journal of Humanities and Social Sciences, 3(18): 248- 256.

Patten, D. M. (1991). Exposure, legitimacy, and social disclosure. Journal of Accounting and Public Policy, 10: 297-308.

Rahman, M. A., \& Muttakin, M. B. (2005). Corporate environmental reporting practices in Bangladesha study of some selected companies. The Cost \& management, 33(4):13-1.

Rakiv, M., Fakhrul, I., \& Raham, R. (2016) Environmental accounting reporting disclosure and company profitability: a case study on listed manufacturing companies of Bangladesh.

Ramamurti, R. (2004). Developing countries and MNEs: Extending and enriching the research agenda. Journal of International Business Studies, 35(4):277-83.

Robert, C. B. (1991). Environmental disclosure. A note on reporting practices in mainland Europe. Accounting, Auditing \& Accountability Journal, 4(3).

Waddock, S. A., \& Graves, S. B. (1997). The corporate social performance-financial performance link. Strategic Management Journal, 18 (4): 303-319. 